\title{
Corrosion of 304SS in acidic and neutral media as a function of molybdate ions concentration
}

\author{
Ahmed S. Alshamsi \\ Department of Chemistry, College of Science, United Arab Emirates University, Al-Ain, UAE \\ Email: a.alshamsi@uaeu.ac.ae
}

\begin{abstract}
The electrochemical behavior of 304SS stainless steels has been investigated in acidic and neutral media at $22{ }^{\circ} \mathrm{C}$ as a function of molybdate ions concentration. Corrosion techniques that have been used include potentiostatic polarization, polarization resistance, and cyclic polarization measurements. Measurements indicate that molybdate ions are very effective in improving resistance to general corrosion of $304 \mathrm{SS}$ when tested in $1 \mathrm{M} \mathrm{H}_{2} \mathrm{SO}_{4}$ and become less effective in the presence of chlorides. More importantly, low concentrations of molybdates have detrimental effect on the corrosion resistance of $304 \mathrm{SS}$ tested in $1 \mathrm{M} \mathrm{H}_{2} \mathrm{SO}_{4}+0.5 \mathrm{M} \mathrm{NaCl}$; relatively high concentrations of molybdate ions are needed in order to exhibit inhibition effect. Furthermore, the presence of molybdate ions in sufficient concentrations enhances the resistance to pitting corrosion. It is suggested that molybdate ions increase the resistance to general and pitting corrosion by lowering the current densities in active and passive regions, enhancing passivation in the process.
\end{abstract}

Keywords: Stainless Steel, Corrosion, Molybdate, Chloride, Sulfuric acid

\section{Introduction}

Environment-friendly, also known as a green inhibitor, molybdate ions $\left(\mathrm{MoO}_{4}{ }^{2-}\right)$ have been of interest as a corrosion inhibitor due to their very low toxicity which makes them a candidate to replace chromate (toxic) as a corrosion inhibitor [1]. It is well established that alloying Mo to steels reduces the steel's susceptibility to localized (pitting) corrosion in marine and chemical environments [2]. It has been reported that alloying Mo to the steel or adding $\mathrm{MoO}_{4}{ }^{2-}$ ions have the same effect in terms of increasing repassivation rate and enhancing resistance to localized corrosion [3, 4 , $5,6,7]$. It was proposed that in acidic-chloride solutions, molybdenum may dissolve as molybdate and consequently reacts with $\mathrm{Fe}$ cations forming insoluble molybdate precipitates and as a result hindering the transpassive reaction leading to lower current densities [6]. Others argue that the formation of Mo-rich stable oxide film $\left(\mathrm{MoO}_{3}\right)$ in the outer region of the passive film is responsible for the enhanced corrosion resistance of stainless steel tested in acidic solutions [8]. Interestingly, a minimum concentration of $5 \mathrm{wt} \%$ of Mo was needed in order to achieve positive results in Fe-Mo alloys and concentrations below $5 \mathrm{Wt} \%$ were reported to have detrimental effects on repassivation kinetics [3]. Furthermore, it was suggested that the addition of molybdate ions affects both passivity-lower passive current densities were observed- and pit nucleation by deactivating the sites at which pit formation occurs and by reducing the size of the pits, resulting in making these pits more difficult to develop into stable pits [9]. Others argued that the major improvement in the corrosion resistance of Mo-containing stainless steels was not related to Mo preventing pit initiation, but related to reduction of active dissolution rates of salt-free surfaces by Mo leading in the process to repassivation and termination of localized corrosion [10]. Some investigators concluded that the beneficial effect of alloyed Mo and $\mathrm{MoO}_{4}{ }^{2-}$ was inhibiting metastable pitting corrosion as current transients observed in the passive region at potentials below the pitting potentials decreased with added molybdate [7]. On the contrary to the above, other investigators reported that the presence of molybdate ions, especially at low concentrations, had had detrimental effect on the corrosion resistance of various metals and alloys- including 304SS tested in acidic-chloride solutions- with molybdate ions acting as a corrosion accelerator and with the inhibition efficiency decreasing with increasing molybdate ions concentration $[11,12,13,14]$. From the above, it is clear that conflicting results have been reported on the inhibition efficiency of molybdate ions. It seems that the choice of metal (alloy) to be tested and the testing conditions such as the concentration of the testing media, the molybdate ions concentration, the $\mathrm{pH}$ (acidic vs. neutral), the presence of chloride, temperature, and heat-treatment influence molybdate ions inhibition. Furthermore, while it is generally accepted that $\mathrm{Mo}$ and $\mathrm{MoO}_{4}{ }^{2-}$ act the same way, there is no widely accepted mechanism on how Mo or $\mathrm{MoO}_{4}{ }^{2-}$ enhances 
the corrosion resistance of steels. The main objective of this study is to further investigate the effect of $\mathrm{MoO}_{4}{ }^{2-}$ on both general and localized corrosion of 304SS in neutral and acidic solutions in the presence and absence of chloride ions and to shed light on how the presence of chloride ions and the $\mathrm{pH}$ influence the inhibition efficiency of molybdate ions.

\section{Material and methods}

304 stainless steel wire ( $\mathrm{Fe} / \mathrm{Cr} 19 / \mathrm{Ni11}$ ), supplied by Alfa Aesar, was tested (as received) in $1 \mathrm{M} \mathrm{H}_{2} \mathrm{SO}_{4}, 0.5 \mathrm{M} \mathrm{NaCl}$, and $1 \mathrm{M} \mathrm{H}_{2} \mathrm{SO}_{4}+0.5 \mathrm{M} \mathrm{NaCl}$ solutions as a function of molybdate ions concentration at $22{ }^{\circ} \mathrm{C} \pm 1{ }^{\circ} \mathrm{C}$. The 304 stainless steel wire, $1 \mathrm{~mm}$ in diameter, was coated with epoxy leaving the cross sectional area $\left(7.85 \times 10^{-3} \mathrm{~cm}^{2}\right)$ exposed to the testing solution. Prior to each experiment the sample was wet-ground using 240 to 600 grit $\mathrm{SiC}$ papers, cleaned with distilled water, and placed in a 3-electrode cell with Pt used as a counter electrode and saturated calomel electrode, SCE, (+242 mV vs. standard hydrogen electrode) as a reference electrode. Standard corrosion techniques that have been employed include the polarization resistance vs. time $\left(R_{p} v s . t\right)$ measurements, potentiostatic measurements, and cyclic polarizations measurements. Cyclic polarization measurements were conducted using a scanning rate of $1.0 \mathrm{mVs}^{-1}$ with the scans initiated at $-500 \mathrm{mV}$, scanned to $+1100 \mathrm{mV}$ or until a threshold current density of $100 \mathrm{~mA} \mathrm{~cm}$ is reached, and then reversed to $-500 \mathrm{mV}$. The $R_{p}$ vs. $t$ measurements were conducted using a scanning rate of $0.5 \mathrm{mV} \mathrm{s}^{-1}$ with experiments conducted within $\pm 20 \mathrm{mV}$ vs. the corrosion potential $\left(\mathrm{E}_{\mathrm{c}}\right)$. Ten measurements were collected per experiment with 10 minutes time interval between measurements. The potentiostatic experiments were conducted at applied potentials of $+700 \mathrm{mV}$ in $0.5 \mathrm{M} \mathrm{NaCl}$ and at $+1000 \mathrm{mV}$ in $1 \mathrm{M} \mathrm{H}_{2} \mathrm{SO}_{4}+0.5 \mathrm{M} \mathrm{NaCl}$. Both applied potentials were in the pitting corrosion range where pitting corrosion was expected to occur. No potentiostatic experiments were conducted in the non-pitting $1 \mathrm{M} \mathrm{H}_{2} \mathrm{SO}_{4}$ solution. Magnetic stirring with a constant rate was maintained in all experiments. The corrosion potential, $\mathrm{E}_{\mathrm{c}}$, was monitored for 30 minutes prior to starting the polarization experiments. An average of three independent experiments was conducted for a given set of conditions in order to verify the results. . Data were collected automatically with the aid of a potentiostat/galvanstat (Gamry G750). All data analysis and extrapolations were performed using Gamry corrosion software (Gamry Echem Analyst).

\section{Results and discussion}

\subsection{Testing in $1.0 \mathrm{M} \mathrm{H}_{2} \mathrm{SO}_{4}$}

Figures $1 \mathrm{a}$ and $1 \mathrm{~b}$ show the cyclic polarization plots of $304 \mathrm{SS}$ tested in $1 \mathrm{M} \mathrm{H}_{2} \mathrm{SO}_{4}$ as a function of molybdate ions concentration. Examination of the Figures clearly shows that the addition of molybdate ions shifts the corrosion potential, $\mathrm{E}_{\mathrm{c}}$, into the noble direction, combined with about one order of magnitude reduction in both the critical current densities and the passive current densities. No hysteresis is seen indicating the non-pitting nature of the solutions.

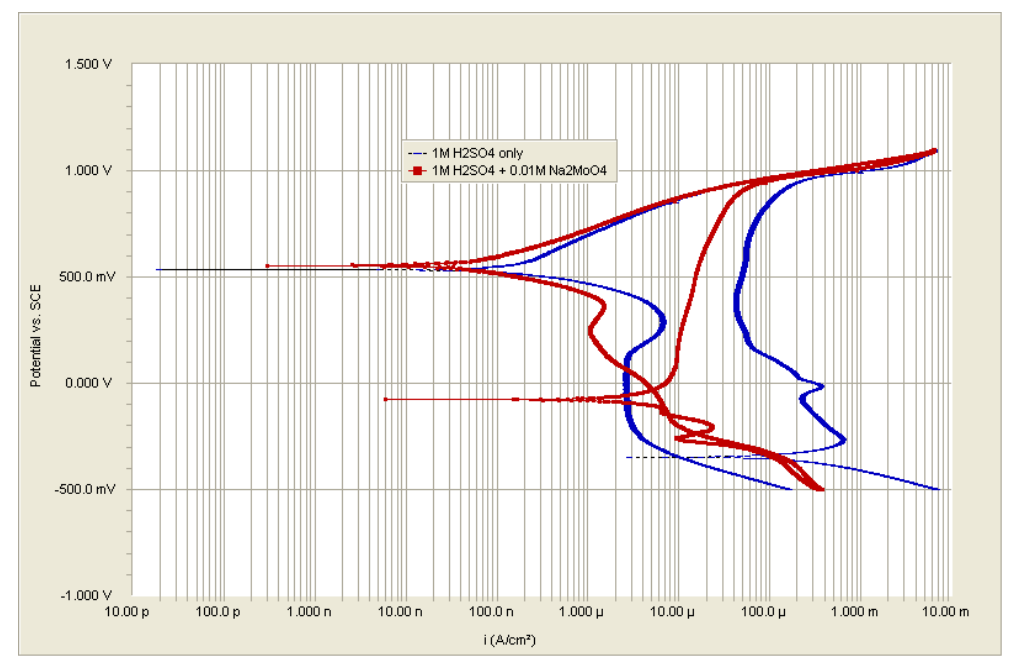

Fig. 1a: Cyclic polarization curves of $304 \mathrm{SS}$ in $1.0 \mathrm{M} \mathrm{H}_{2} \mathrm{SO}_{4}$ as a function of $\mathrm{Na}_{2} \mathrm{MoO}_{4}$ concentration. 


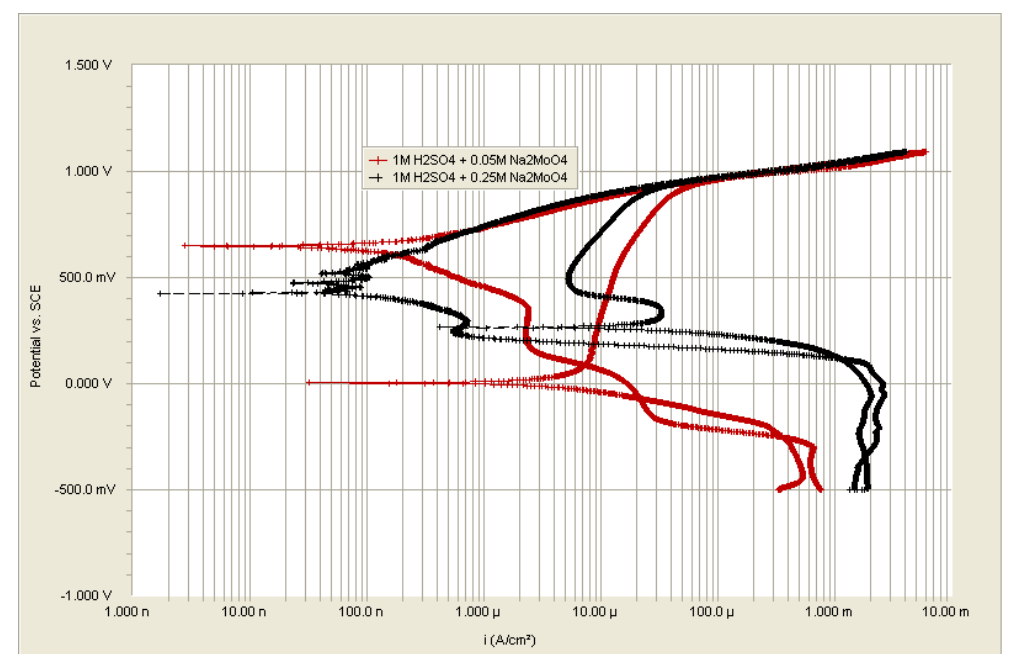

Fig. 1b: Cyclic polarization curves of $304 \mathrm{SS}$ in $1.0 \mathrm{M} \mathrm{H}_{2} \mathrm{SO}_{4}$ as a function of $\mathrm{Na}_{2} \mathrm{MoO}_{4}$ concentration.

Figure 2 shows the $\mathrm{R}_{\mathrm{p}}$ vs. $\mathrm{t}$ for $304 \mathrm{SS}$ tested in $1.0 \mathrm{M} \mathrm{M} \mathrm{H}_{2} \mathrm{SO}_{4}$ as a function of molybdate ions concentration. Inspection of the Figure shows that the addition of molybdate ions as small as $0.01 \mathrm{M}$ results in significant increase in the $\mathrm{Rp}$ values. Interestingly, further increase in the molybdate ions concentration has little effect on the $R_{p}$ values. $i_{c}=$ $B / R_{p}$ where $B$ is a constant given by $B=\beta a \beta c /[2.3(\beta a+\beta c)]$ and $\beta a$ and $\beta c$ are the anodic and cathodic Tafel slopes extrapolated from the polarization curves; respectively.

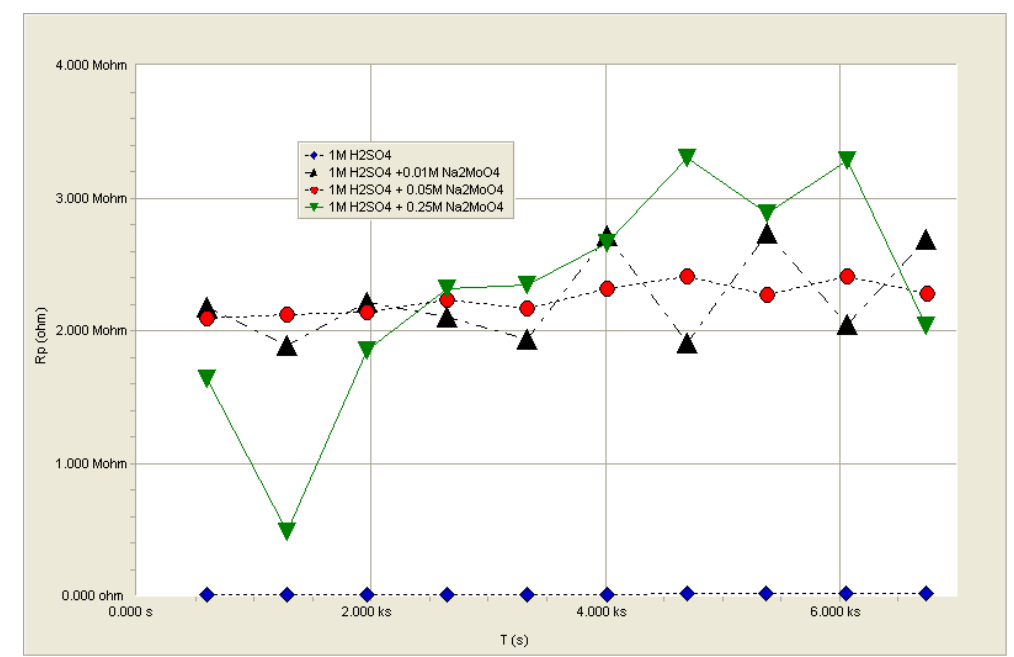

Fig. 2: $R_{p} v s$. time measurements of $304 \mathrm{SS}$ tested in $1.0 \mathrm{M} \mathrm{H}_{2} \mathrm{SO}_{4}$ as a function of $\mathrm{Na}_{2} \mathrm{MoO}_{4}$ concentration.

Table 1 shows $E_{c}, R_{p}$, and the inhibition efficiency (IE) values for $304 \mathrm{SS}$ tested in $1 \mathrm{M} \mathrm{H}_{2} \mathrm{SO}_{4}$ as a function of molybdate ions concentration. In Table 1 , as the case with Tables 2 and 3 , the $R_{p}$ values are the average of 10 readings from the $\mathrm{R}_{\mathrm{p}}$ vs. $t$ curves. The IE values are calculated using the equation:

$$
\operatorname{IE}(\%)=\left[\left(R_{p(i)}-R_{p}\right) / R_{p(i)}\right] \times 100 \%
$$

The $R_{p}$ and $R_{p(i)}$ are the polarization resistance in the absence and in the presence of molybdate ions, respectively. Based on the estimated IE values, molybdate ions are an excellent corrosion inhibitor for $304 \mathrm{SS}$ tested in $1 \mathrm{M} \mathrm{H}_{2} \mathrm{SO}_{4}$.

Table 1: Electrochemical parameters of $304 \mathrm{SS}$ in $1 \mathrm{M} \mathrm{H}_{2} \mathrm{SO}_{4}$ as a function of molybdate ions concentration.

\begin{tabular}{cccc}
\hline Solution & $\mathbf{E}_{\mathbf{c}}(\mathbf{m V})$ & $\mathbf{R}_{\mathbf{p}}\left(\boldsymbol{\Omega} \mathbf{~ c m}^{2}\right)$ & IE $(\boldsymbol{\%})$ \\
\hline $1 \mathrm{M} \mathrm{H}_{2} \mathrm{SO}_{4}$ & -347 & 106.4 & - \\
$1 \mathrm{M} \mathrm{H}_{2} \mathrm{SO}_{4}+0.01 \mathrm{M} \mathrm{Na}_{2} \mathrm{MoO}_{4}$ & -77.1 & $1.758 \times 10^{+4}$ & 99.4 \\
$1 \mathrm{M} \mathrm{H}_{2} \mathrm{SO}_{4}+0.05 \mathrm{M} \mathrm{Na}_{2} \mathrm{MoO}_{4}$ & +3.64 & $1.762 \times 10^{+4}$ & 99.4 \\
$1 \mathrm{M} \mathrm{H}_{2} \mathrm{SO}_{4}+0.25 \mathrm{M} \mathrm{Na}_{2} \mathrm{MoO}_{4}$ & +250 & $1.791 \times 10^{+4}$ & 99.4 \\
\hline
\end{tabular}




\subsection{Testing in $1.0 \mathrm{M} \mathrm{H} \mathrm{HO}_{4}+0.5 \mathrm{M} \mathrm{NaCl}$}

Figures $3 \mathrm{a}$ and $3 \mathrm{~b}$ show the cyclic polarization plots of $304 \mathrm{SS}$ tested in $1 \mathrm{M} \mathrm{H}_{2} \mathrm{SO}_{4}+0.5 \mathrm{M} \mathrm{NaCl}$ as a function of molybdate ions concentration. Examination of the Figures clearly shows the addition of molybdate ions shifts the $\mathrm{E}_{\mathrm{c}}$ into the noble direction, combined with about two orders of magnitudes reduction in the critical current densities and about one order of magnitude reduction in the passive current densities. Interestingly, while hysteresis loops are expected to appear in the presence of chloride ions, such loops increase in size with increasing molybdate ions concentrations as shown in Figures 3a and 3b. Such behavior indicates that molybdate ions might have detrimental effect on the pitting resistance of the steel under the conditions tested. Such hypothesis was further tested using potentiostatic polarization.

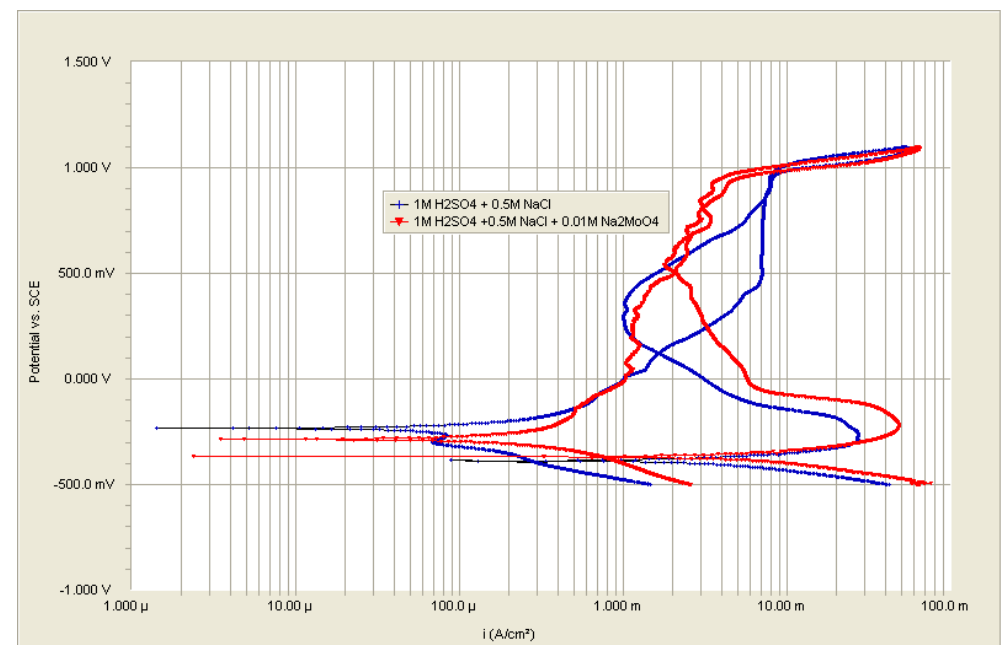

Fig. 3a: Cyclic polarization curves of 304SS in $1.0 \mathrm{M} \mathrm{H}_{2} \mathrm{SO}_{4}+0.5 \mathrm{M} \mathrm{NaCl}$ as a function of $\mathrm{Na}_{2} \mathrm{MoO}_{4}$ concentration.

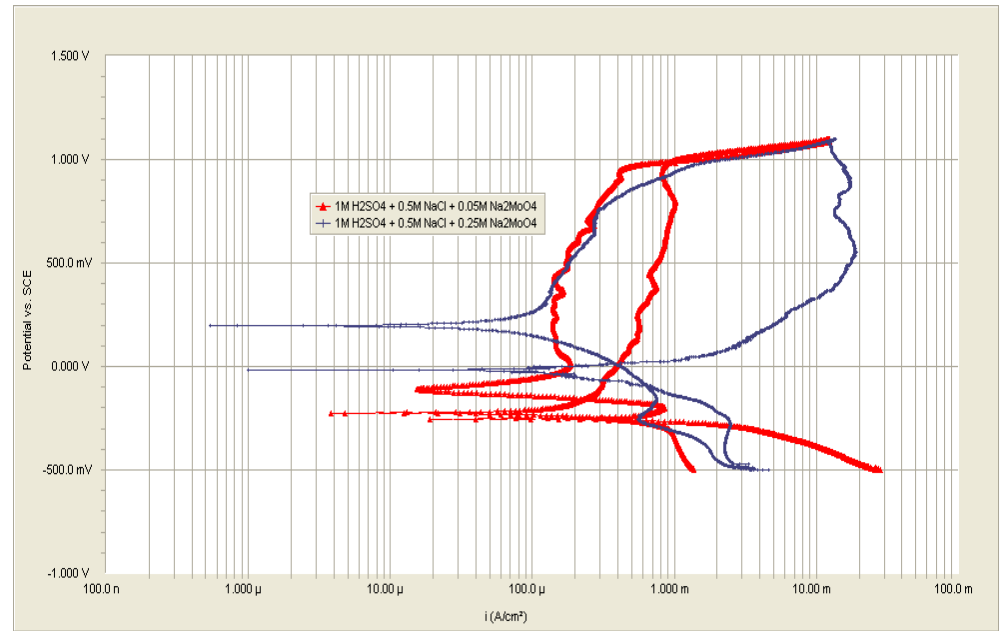

Fig. 3b: Cyclic polarization curves of $304 \mathrm{SS}$ in $1.0 \mathrm{M} \mathrm{H}_{2} \mathrm{SO}_{4}+0.5 \mathrm{M} \mathrm{NaCl}$ as a function of $\mathrm{Na}_{2} \mathrm{MoO}_{4}$ concentration.

To further investigate the effect of molybdate ions on the pitting of 304SS, potentiostatic tests have been conducted at applied potential of $1000 \mathrm{mV}$ where pitting is expected. Figure 4a shows the potentiostatic polarization of 304SS in the absence of molybdate ions. The Figure shows that the current density increases with time reaching about $190 \mathrm{~mA} \mathrm{~cm}^{-2}$ after 10 minutes. The increase is associated with current densities fluctuations indicating pits formation. Figures 4(b,c, and d) are potentiostatic curves in the presence of different concentrations of molybdate ions added at about the $120 \mathrm{~s}$ mark. It is clear from the Figures that while increasing the concentration of molybdate up to $0.25 \mathrm{M}$ doesn't inhibit pitting completely, pitting is significantly reduced in the presence of molybdate with current density reaching a maximum of about 4 and $6 \mathrm{~mA} \mathrm{~cm}^{-2}$ in the presence of $0.05 \mathrm{M}$ and $0.25 \mathrm{M}$ molybdate ions, respectively; much less than the value reported in the absence of molybdate ions. 


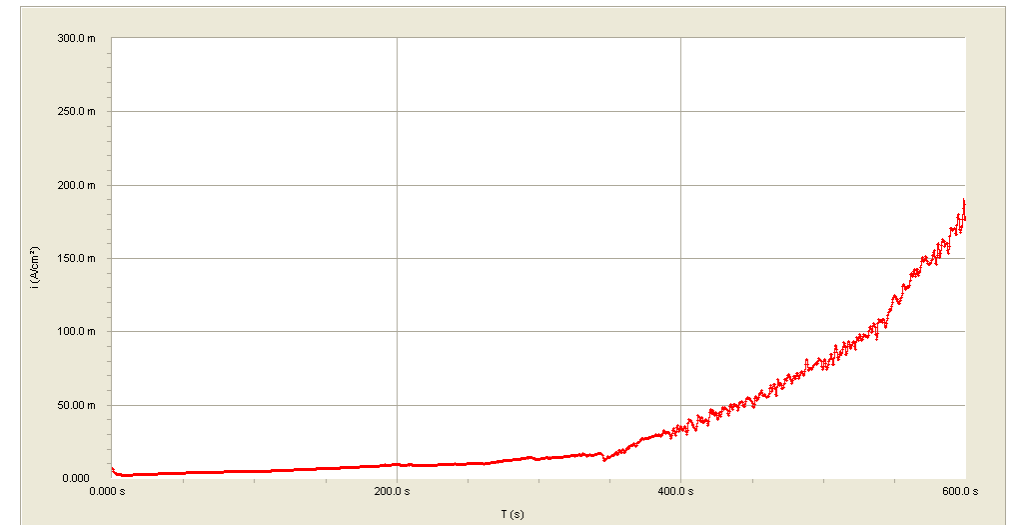

Fig. 4a: Potentiostatic polarization curves of $304 \mathrm{SS}$ in $1 \mathrm{M} \mathrm{H}_{2} \mathrm{SO}_{4}+0.5 \mathrm{M} \mathrm{NaCl}$ in the absence of molybdate ions at $\mathrm{E}_{\text {applied }}=+1000 \mathrm{mV}$ (in the pitting region).

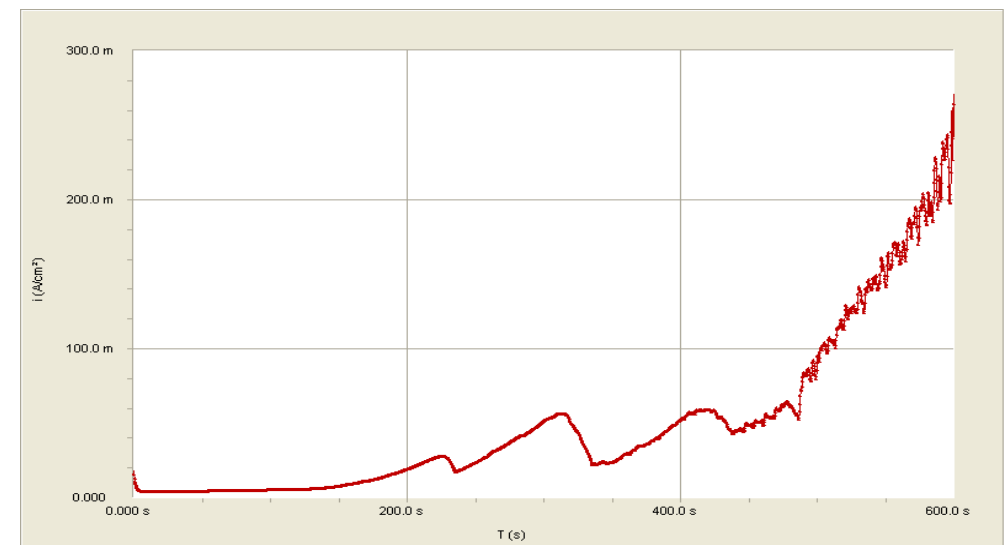

Fig. 4b: Potentiostatic polarization curves of $304 \mathrm{SS}$ in $1 \mathrm{M} \mathrm{H}_{2} \mathrm{SO}_{4}+0.5 \mathrm{M} \mathrm{NaCl}$ in the presence of molybdate ions at $\mathrm{E}_{\text {applied }}=+1000 \mathrm{mV}$ (in the pitting region). Note: molybdate ions $(0.01 \mathrm{M})$ were added at about the $120 \mathrm{~s}$ mark.

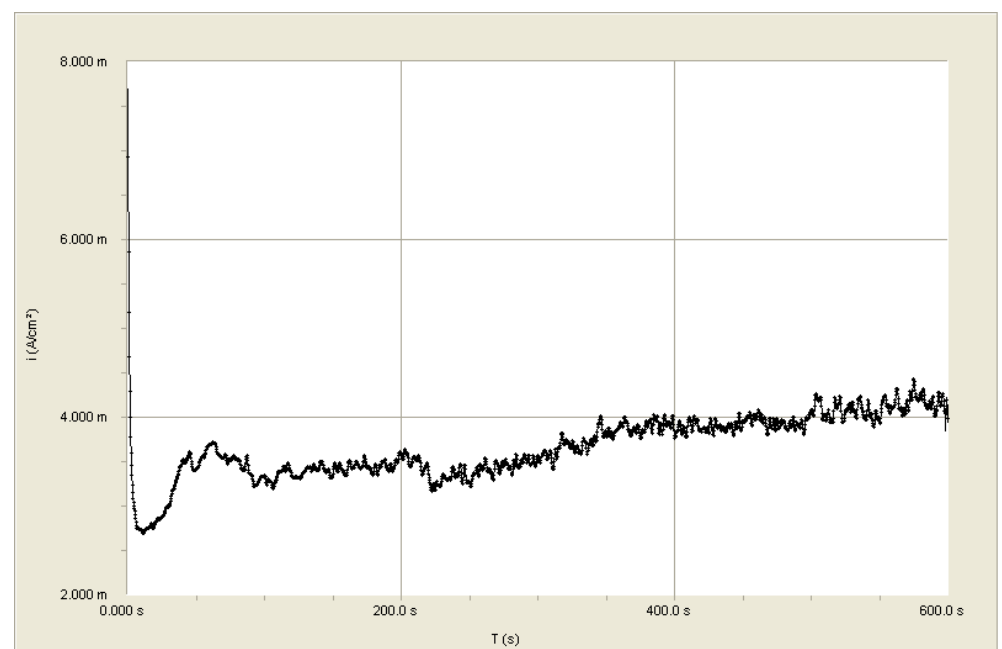

Fig. 4c: Potentiostatic polarization curves of $304 \mathrm{SS}$ in $1 \mathrm{M} \mathrm{H}_{2} \mathrm{SO}_{4}+0.5 \mathrm{M} \mathrm{NaClin}$ the presence of molybdate ions at $\mathrm{E}_{\text {applied }}=+1000 \mathrm{mV}$ (in the pitting region). Note: molybdate ions $(0.05 \mathrm{M})$ were added at about the $120 \mathrm{~s}$ mark. 


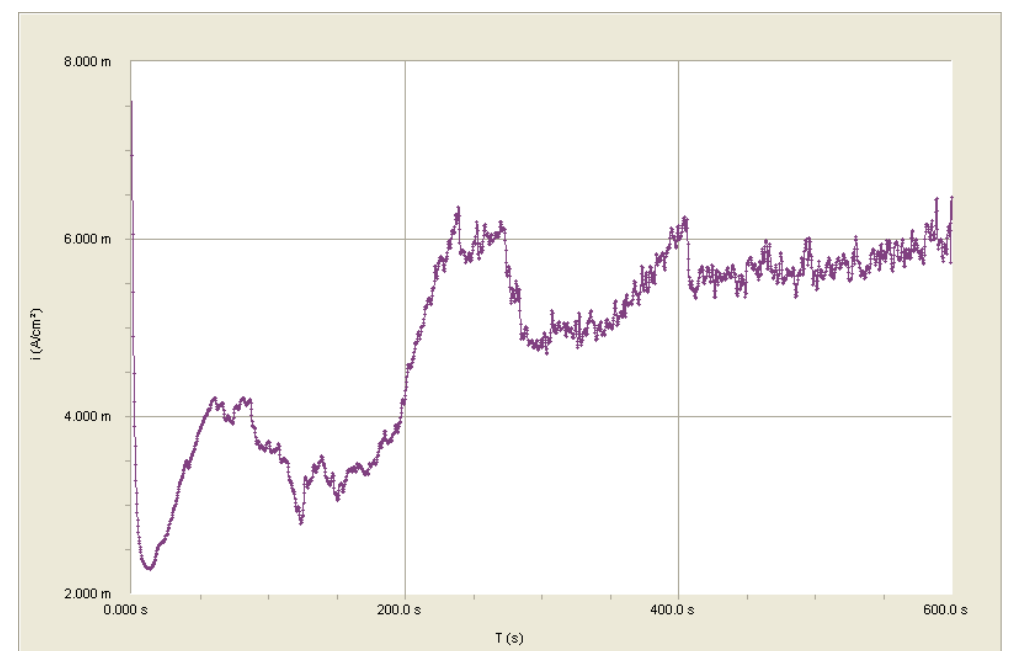

Fig. 4d: Potentiostatic polarization curves of $304 \mathrm{SS}$ in $1 \mathrm{M} \mathrm{H}_{2} \mathrm{SO}_{4}+0.5 \mathrm{M} \mathrm{NaCl}$ in the presence of molybdate ions at $\mathrm{E}_{\text {applied }}=+1000 \mathrm{mV}$ (in the pitting region). Note: molybdate ions $(0.25 \mathrm{M})$ were added at about the 120 s mark.

Figure 5 shows the $\mathrm{R}_{\mathrm{p}}$ vs. $\mathrm{t}$ for $304 \mathrm{SS}$ tested in $1.0 \mathrm{M} \mathrm{M} \mathrm{H} \mathrm{H}_{2}+0.5 \mathrm{M} \mathrm{NaCl}$ as a function of molybdate ions concentration. The Figure clearly shows that the presence of small concentrations of molybdate ions, less than $0.05 \mathrm{M}$, results in lower $R_{p}$ values and consequently higher corrosion rates. Higher $R_{p}$ values are obtained at relatively high concentration of molybdate ions. Such detrimental effect at low concentrations of molybdate, while surprising, is in agreement with the literature. Molybdate ions were reported to act as a corrosion accelerator for $\mathrm{Al}$ was tested in $\mathrm{HCl}$ [12], mild steel tested in acidic-chloride solutions [13], and 304SS tested in $\mathrm{HCl}$ in the presence of low concentrations of molybdate ions [14].

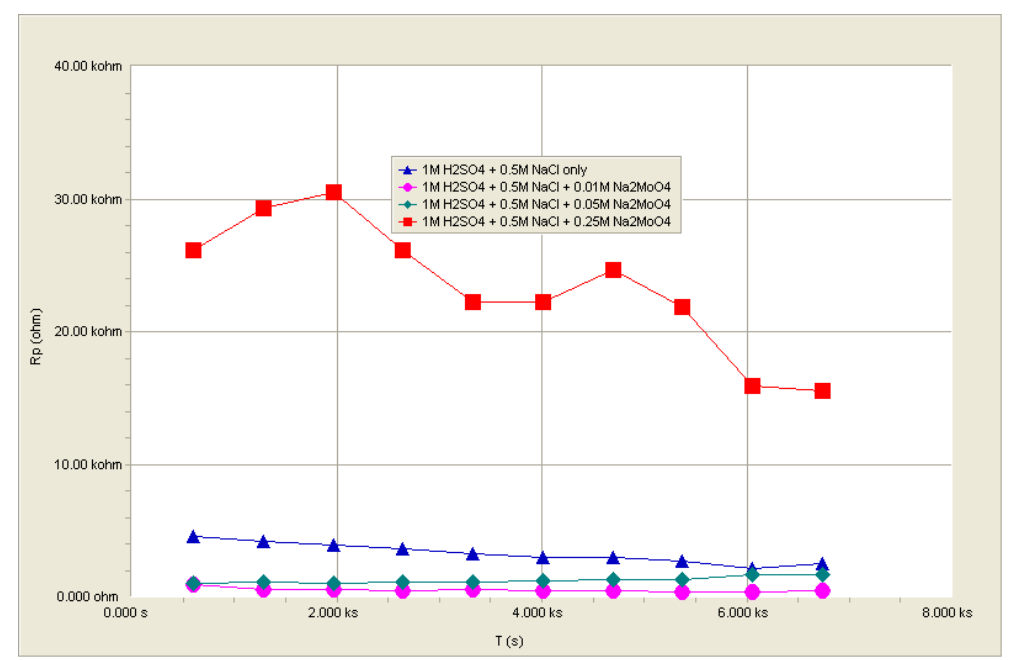

Fig. 5: $R_{p}$ vs. time measurements of $304 \mathrm{SS}$ tested in $1.0 \mathrm{M} \mathrm{H}_{2} \mathrm{SO}_{4}+0.5 \mathrm{M} \mathrm{NaCl}$ as a function of $\mathrm{Na}_{2} \mathrm{MoO}_{4}$ concentration.

Table 2 shows $\mathrm{E}_{\mathrm{c}}, \mathrm{R}_{\mathrm{p}}$, and IE for $304 \mathrm{SS}$ tested in $1 \mathrm{M} \mathrm{H}_{2} \mathrm{SO}_{4}+0.5 \mathrm{M} \mathrm{NaCl}$ as a function of molybdate ions. Comparing Table 2 and Table 1 indicates that the $\mathrm{R}_{\mathrm{p}}$ values in the presence of chloride are much lower than the ones reported in the absence of chloride. In addition, data in Table 2 show that small concentrations of molybdate ions are detrimental to the corrosion resistance of $304 \mathrm{SS}$ tested in $1 \mathrm{M} \mathrm{H}_{2} \mathrm{SO}_{4}+0.5 \mathrm{M} \mathrm{NaCl}$.

Table 2: Electrochemical parameters of 304SS in $1 \mathrm{M} \mathrm{H}_{2} \mathrm{SO}_{4}+0.5 \mathrm{M} \mathrm{NaCl}$ as a function of molybdate ions concentration.

\begin{tabular}{|c|c|c|c|}
\hline Solution & $\mathbf{E}_{\mathrm{c}}(\mathbf{m V})$ & $\mathbf{R}_{\mathrm{p}}\left(\boldsymbol{\Omega} \mathbf{c m}^{2}\right)$ & IE $(\%)$ \\
\hline $1 \mathrm{M} \mathrm{H}_{2} \mathrm{SO}_{4}+0.5 \mathrm{M} \mathrm{NaCl}$ & -383 & 25.79 & - \\
\hline $1 \mathrm{M} \mathrm{H}_{2} \mathrm{SO}_{4}+0.5 \mathrm{M} \mathrm{NaCl}+0.01 \mathrm{M} \mathrm{Na}_{2} \mathrm{MoO}_{4}$ & -365 & 4.171 & -518.2 \\
\hline $1 \mathrm{M} \mathrm{H}_{2} \mathrm{SO}_{4}+0.5 \mathrm{M} \mathrm{NaCl}+0.05 \mathrm{M} \mathrm{Na}_{2} \mathrm{MoO}_{4}$ & -252 & 9.797 & -163.2 \\
\hline $1 \mathrm{M} \mathrm{H}_{2} \mathrm{SO}_{4}+0.5 \mathrm{M} \mathrm{NaCl}+0.25 \mathrm{M} \mathrm{Na}_{2} \mathrm{MoO}_{4}$ & +201 & 184.2 & +86.0 \\
\hline
\end{tabular}




\subsection{Testing in $0.5 \mathrm{M} \mathrm{NaCl}$}

Figures $6 \mathrm{a}$ and $6 \mathrm{~b}$ show the cyclic polarization plots of $304 \mathrm{SS}$ tested in $0.5 \mathrm{M} \mathrm{NaCl}$ as a function of molybdate ions concentration. Inspection of the Figures shows that the addition of molybdates has little influence on the passive current densities and on the onset of pitting. Interestingly, the predetermined threshold current density of $100 \mathrm{~mA} \mathrm{~cm}{ }^{-2}$ was reached at higher potentials with increasing molybdate ions concentrations indicating the increase in resistance to pitting with increasing molybdate ion concentration.

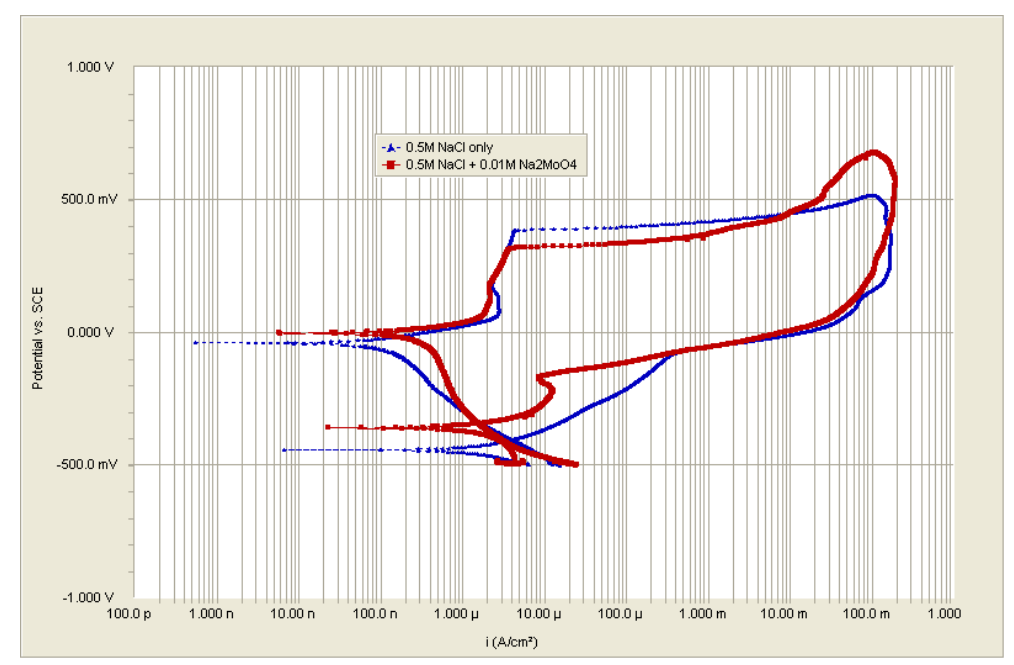

Fig. 6a: Cyclic polarization curves of $304 \mathrm{SS}$ in $0.5 \mathrm{M} \mathrm{NaCl}$ as a function of $\mathrm{Na}_{2} \mathbf{M o O}_{4}$ concentration.

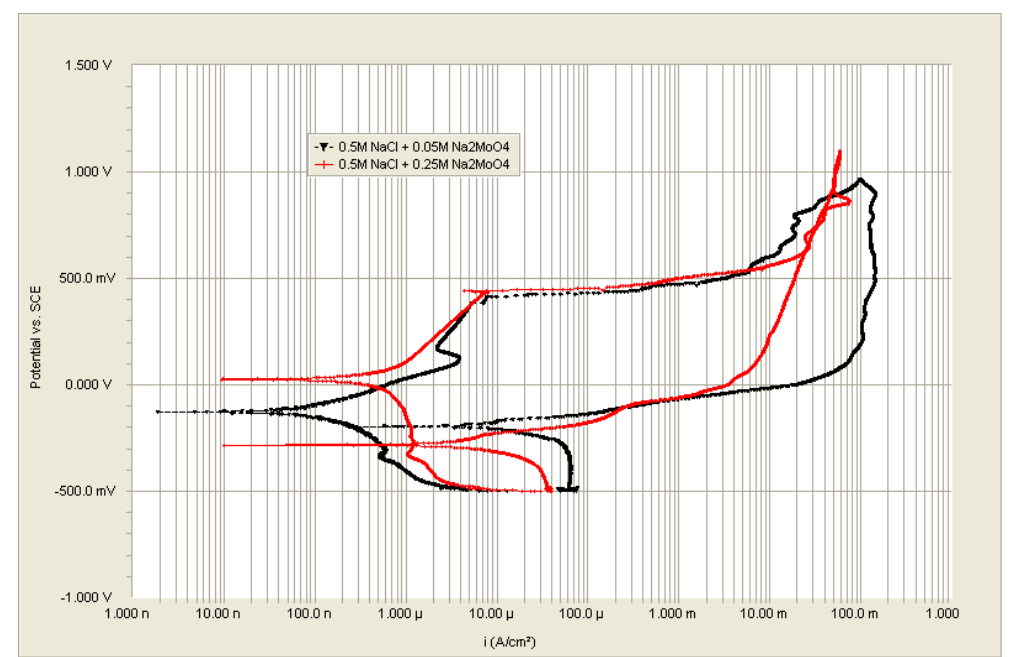

Fig. 6b: Cyclic polarization curves of $304 \mathrm{SS}$ in $0.5 \mathrm{M} \mathrm{NaCl}$ as a function of $\mathrm{Na}_{2} \mathrm{MoO}_{4}$ concentration.

To further investigate the effect of molybdate ions on pitting, potentiostatic tests have been conducted at applied potential of $700 \mathrm{mV}$ in the pitting region. Figure 7 shows that a sharp decrease followed by gradual decrease in the current densities when molybdate ions were added. Such behavior indicates that molybdate ions are good inhibitor of pitting corrosion under the testing conditions.

Figure 8 shows the $\mathrm{R}_{\mathrm{p}}$ vs. $\mathrm{t}$ for $304 \mathrm{SS}$ tested in $0.5 \mathrm{M} \mathrm{M} \mathrm{NaCl}$ as a function of molybdate ions concentrations. Inspection of the Figure shows that the addition of molybdate ions at concentrations up to $0.05 \mathrm{M}$ has little influence on the $R_{p}$ values with overlapping $R_{p}$ values. Noticeable increase in the $R_{p}$ values is obtained in the presence of $0.25 M$ molybdate ions. Table 3 shows that a maximum of $25 \%$ IE is obtained. 


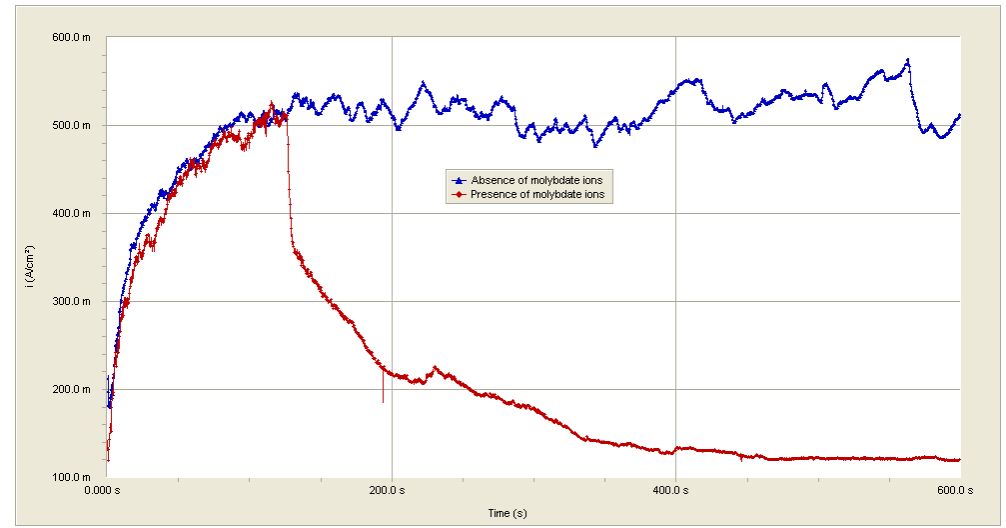

Figure 7: Potentiostatic polarization curves of $304 \mathrm{SS}$ in $0.5 \mathrm{M} \mathrm{NaCl}$ in the absence and presence of molybdate ions at $\mathrm{E}_{\text {applied }}=+700 \mathrm{mV}$ (in the pitting region). Note: molybdate ions $(0.04 M)$ were added at about the 130 s mark.

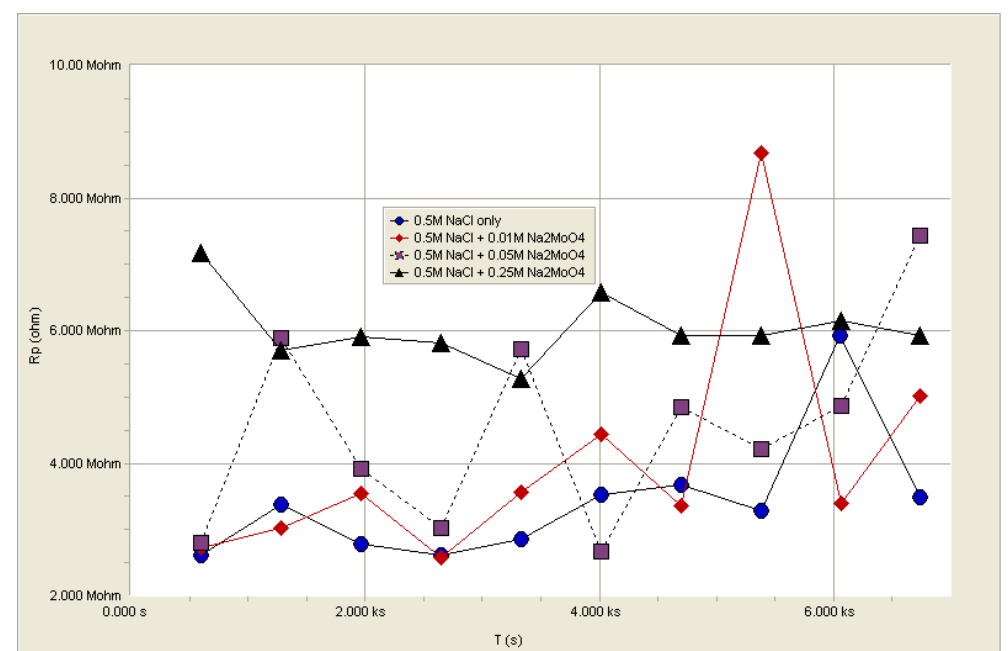

Fig. 8: $R_{p} v s$. time measurements of $304 \mathrm{SS}$ tested in $0.5 \mathrm{M} \mathrm{NaCl}$ as a function of $\mathrm{Na}_{2} \mathrm{MoO}_{4}$ concentration.

Table 3: Electrochemical parameters of $304 \mathrm{SS}$ in $0.5 \mathrm{M} \mathrm{NaCl}$ as a function of molybdateions concentration.

\begin{tabular}{cccc}
\hline Solution & $\mathbf{E}_{\mathbf{c}}(\mathbf{m V})$ & $\mathbf{R}_{\mathbf{p}}\left(\mathbf{\Omega} \mathbf{~ c m}^{2}\right)$ & IE $(\boldsymbol{\%})$ \\
\hline $0.5 \mathrm{M} \mathrm{NaCl}$ & -37.1 & $2.678 \times 10^{+4}$ & - \\
$0.5 \mathrm{M} \mathrm{NaCl}+0.01 \mathrm{M} \mathrm{Na} \mathrm{MoO}_{4}$ & 0.0 & $3.165 \times 10^{+4}$ & +15.4 \\
$0.5 \mathrm{M} \mathrm{NaCl}+0.05 \mathrm{M} \mathrm{Na}_{2} \mathrm{MoO}_{4}$ & -123.1 & $3.562 \times 10^{+4}$ & +24.8 \\
$0.5 \mathrm{M} \mathrm{NaCl}+0.25 \mathrm{M} \mathrm{Na}_{2} \mathrm{MoO}_{4}$ & +30.8 & $3.251 \times 10^{+4}$ & +17.6 \\
\hline
\end{tabular}

\section{Conclusions}

1. Molybdate ions are an excellent corrosion inhibitor of $304 \mathrm{SS}$ tested in $1 \mathrm{M} \mathrm{H}_{2} \mathrm{SO}_{4}$ with an inhibition efficiency reaching more than $99 \%$. However, the presence of chloride ions reduces the inhibition efficiency significantly.

2. More importantly, low concentrations of molybdate ions might have detrimental effect on the corrosion resistance of 304SS tested in acidic-chloride solutions.

3. Molybdate ions are less inhibitive in $0.5 \mathrm{M} \mathrm{NaCl}$ in comparison to $1 \mathrm{M} \mathrm{H}_{2} \mathrm{SO}_{4}$ with a maximum inhibition efficiency of about $25 \%$ in the former.

4. Molybdate ions, as a corrosion inhibitor, should be used with caution; the concentration of the testing media, the concentration of molybdate ions, the $\mathrm{pH}$, and the presence of chloride ions contribute to the inhibition of molybdate ions.

5. It is proposed that molybdate ions enhance resistance to pitting by lowering the current densities in the active, critical, and passive ranges to a critical values in which below these values, metastable pits, if form, fail to grow into stable ones. 


\section{Acknowledgements}

I would like to express my sincere appreciation to the Research Affairs at the United Arab Emirates University for their support of this project. I would also like to express my gratitude to the department of chemistry at the UAEU for providing the facilities to carry out this project.

\section{References}

[1] V. S. Sastri, Green Corrosion Inhibitors, John Wiley and Sons, New Jersey (2011)

[2] A. J. Sedriks, Corrosion of Stainless Steels, 2nd ed., John Wiley and Sons, Inc. (1996)

[3] J. R. Ambrose, Corrosion, 34, 1978, 27-31

[4] T. Kodama and J. R. Ambrose, Corrosion, 33, 1977, 155-161

[5] K. Sugimoto and Y. Sawada, Corrosion, 32, 1976, 347-352

[6] C. R. Clayton and Y. C. Lu, Corrosion Science, 29, 1989, 881-898

[7] S. Virtanen, B. Surber, and P.Nylund, Corrosion Science, 43, 2001, 1165-1177

[8] A. Pardo, M. C. Merino, A. E. Coy, F. Viejo, R. Arrabal, and E. Matykina, Corrosion Science, 50, 2008, 780-794

[9] O. Ilevbare and G. T. Burstein, Corrosion Science, 45, 2003, 1545-1569

[10] H. S. Isaacs and S.-M. Huang, J. Electrochemical Soc., 143, 1996, L277-279

[11] S. A. M. Refaey, Applied Surface Science, 240, 2005, 396-404

[12] Xianghong Li, Shuduan Deng, and Hui Fu, Corrosion Science, 53, 2011, 2748-2753

[13] M. R. Ali, C. M. Mustafa, and M. Habib, Journal of Scientific Research, 1, 2009, 82-91

[14] Ahmed S. Alshamsi, Int. J. Electrochem. Sci., 8, 2013, 591-605 